www.jmscr.igmpublication.org

Index Copernicus Value: 79.54

ISSN (e)-2347-176x ISSN (p) 2455-0450

crossrefDOI: https://dx.doi.org/10.18535/jmscr/v7i1.161

Journal Of Medical Science And Clinical Research

IGM Publication

An official Publication of IGM Publication

\title{
Effect of Pre-Emptive Gabapentin for Post-Operative Analgesia in Vaginal Hysterectomy under Spinal Anaesthesia
}

\author{
Authors \\ Pradipta Kumar Patel ${ }^{1}$, Sumati Kandi ${ }^{2}$, Aparna Sahu ${ }^{3}$, Sapan Kumar Jena ${ }^{4}$ \\ Siddhanta Choudhury ${ }^{5}$, Saurabh Agrawal ${ }^{6}$ \\ ${ }^{1}$ Associate Professor, Department of Anesthesiology, VIMSAR \\ ${ }^{2}$ Assistant Professor, Department of Anesthesiology, VIMSAR \\ 3,4,5,6 Junior Resident, Department of Anesthesiology, VIMSAR
}

\begin{abstract}
Background and Aims: Various drugs and methods have been tried to alleviate postoperative pain, perioperative anxiety, and apprehension. Opioids, Non-steroidal anti-inflammatory drugs, Cyclooxygenase inhibitors, and many local anesthetic techniques have been used, but every approach has their own side effects and limitations. Recent works have shown that gabapentin may have an opioidsparing effect and anxiolytic property, without any respiratory depression, gastrointestinal, hematological, renal and hepatic adverse effects.

We conducted this study to assess the efficacy of a single dose oral gabapentin as pre-emptive analgesia in comparison to placebo for postoperative pain control in adult subjects undergoing vaginal hysterectomy under spinal anesthesia.
\end{abstract}

Material \& Methods: This randomised double-blind study was conducted in 100 ASA grade I and II patients of age 40-60 years posted for abdominal hysterectomy. Patients were divided into two groups of 50 each. Group $G$ received 600mg oral gabapentin 1 hour before vaginal hysterectomy and Group $C$ received placebo. Total abdominal hysterectomy was carried out under spinal anesthesia. Pulse rate, SBP, $\mathrm{DBP}$, and $\mathrm{SpO}_{2}$ over a 24-hour period, Total tramadol consumption, sedation scores, incidence of nausea and vomiting and other adverse effects were noted. Data was analysed with SPSS version 23 using appropriate statistical tests.

Results: There were significantly lower pain scores and reduced analgesic requirements in gabapentin group over a 24-hour period. There was better hemodynamic stability in the gabapentin group. Incidence of nausea, vomiting, and adverse events was higher in patients of gabapentin group, although not significant statistically.

Conclusion: Gabapentin used a pre-emptive analgesic, reduces post-operative analgesic requirements.

Keywords: Gabapentin, Post-operative analgesia, Pre-emptive analgesia, Abdominal Hysterectomy.

\section{Introduction}

Pain is associated with delayed recovery and mobilization in the immediate postoperative period. The most common psychological reactions to acute pain and pain of prolonged duration are anxiety, sleep disturbances and depression, which can increase the suffering of post-surgical patients. In fact, the apprehension of post-surgical pain sometimes overpowers the fear of surgery in patients and their relatives. It is the responsibility 
of the anesthesiologists to provide adequate postoperative analgesia not only to suppress the adverse physiological responses to pain, but also to improve the quality of patient comfort following surgery. Various drugs and methods have been tried to alleviate postoperative pain, perioperative anxiety and apprehension, namely; opioids ${ }^{(1-4)}$ non-steroidal anti- inflammatory drugs (5-7) cyclooxygenase inhibitors $^{(8,9)}$ and various local anaesthetic techniques ${ }^{(10,11)}$ but every approach has its own side effects and limitations. ${ }^{(12-18)}$. Postoperative pain has multiple mechanisms. If analgesia is not provided at an appropriate time, pain sensitization occurs, and analgesia becomes ineffective or inadequate. Preemptive analgesia is defined as anti-nociceptive management which starts before actual nociception and prevents the establishment of altered central processing which amplifies postoperative pain ${ }^{(19-24)}$. Recently studies have shown that gabapentin may have an opioid sparing effect and anxiolytic property without causing respiratory depression or gastrointestinal, haematological, renal and hepatic adverse effects. Gabapentin, a structural analogue of gamma amino butyric acid, introduced in 1993, and used as an anticonvulsant drug, has been shown to have analgesic properties. It is effective in chronic pain conditions, including post-herpetic neuralgia, diabetic neuropathy, complex regional pain syndrome (CRPS), inflammatory pain, central pain, malignant pain, trigeminal neuralgia, HIVrelated neuropathy, and headache. ${ }^{(25-33)}$. It also has a synergistic effect with morphine. ${ }^{(34)}$. Animal studies have shown that gabapentin reduces mechanical or thermal hyperalgesia ${ }^{(35)}$, ameliorate pain in models of peripheral nerve injury ${ }^{(36)}$, incisional injury ${ }^{(37)}$ and inflammatory injury ${ }^{(38)}$. Various human studies and meta-analysis also have shown that gabapentin premedication can reduce postoperative opioid consumption in first 24 hours in various operations like abdominal hysterectomy, spinal surgery, vaginal hysterectomy, radical mastectomy and laparoscopic cholecystectomy ${ }^{(39-44)}$.
We conducted this study to assess the efficacy of a single dose oral gabapentin as pre-emptive analgesia in comparison to placebo in postoperative pain control in adult subjects undergoing vaginal hysterectomy under spinal anaesthesia.

\section{Material and Methods}

This was a randomised double blinded study conducted after obtaining ethical approval of the Institutional Ethical Committee at VIMSAR Burla. 100 patients aged 40 to 60 years of ASA physical status I and II undergoing elective vaginal hysterectomy under spinal anaesthesia were included. Patient who had contradictions to spinal anaesthesia, patients with mental impairment, patients allergic to gabapentin, uncooperative patients, and those posted for emergency surgery were excluded from the study. Considering a power of $80 \%$ and alpha error of $0.05,46$ patients would be required in each group to detect $10 \%$ or more difference in tramadol consumption. So 50 patients were randomly allocated to each group.

All patients were kept nil per oral 8 hours before surgery but clear fluids were permitted till four hours prior to scheduled time of operation and only one hours before operation gabapentin tablets or placebo (sugar candy) with small sips of water were given. The patients were divided into two groups:

A) Group G -50 patients receiving 600mg oral Gabapentin

B) Group C -50 patients receiving placebo

No sedative premedication other than gabapentin was given to the patients. Upon arrival at operation room all the base line parameters like non-invasive blood pressure (NIBP), peripheral oxygen saturation $\left(\mathrm{SpO}_{2}\right)$, pulse rate, electrocardiography (ECG) were recorded. In all patients, subarachnoid block was performed in sitting position, through midline approach, with 25-gauge Quincke's type needle through $\mathrm{L}_{3}-\mathrm{L}_{4}$ intervertebral spaces by an anaesthesiologist who was not involved in data collection, maintaining 
the standard protocol and strict aseptic measures \& $3.0 \mathrm{ml}$ of $0.5 \%$ hyperbaric bupivacaine. Motor block was assessed by modified Bromage scale and sensory block was assessed by cold touch with a spirit-soaked cotton ball. After achieving adequate sensory block up to $\mathrm{T}_{10}$ level, and motor block (Bromage scale 4) surgery was allowed.

Blood pressure including systolic and diastolic and mean arterial pressure was measured every 2 minutes for first 30 minutes after the block and then every 15 minutes. ECG and $\mathrm{SpO}_{2}$ were monitored continuously throughout the perioperative period. After the surgery, the patients were shifted to the PACU where pulse rate, systolic blood pressure, diastolic blood pressure, respiratory rate, dizziness were recorded at $0,2,4,6,8,12,18,24$ hour intervals. Postoperative pain was assessed by a $100 \mathrm{~mm}$ VAS $(0=$ no pain, $100=$ worst possible pain) scale at $0,2,4,6,8,12,18$ and $24^{\text {th }}$ hours. Inj. Tramadol $(2 \mathrm{mg} / \mathrm{kg})$ intravenously was given as rescue analgesic whenever patients demanded and/or Pain score reached 40. Hypotension (defined as MAP 20\% less than the baseline value for at least 60 seconds) were treated with Mephenteramine (5-10 $\mathrm{mg}$ in aliquots intravenously) and bradycardia (defined as HR< 50 beats per minutes for at least 60 seconds) was treated with inj. Atropine $0.02 \mathrm{mg} / \mathrm{kg}$ body weight intravenously and incidence were recorded. Time to recovery of motor power were assessed by modified Bromage scale and time for gaining full motor power was noted. The time elapsed between the placements of subarachnoid block and patients' first request for analgesia and/or VAS pain score reached 40 was recorded. Total tramadol consumption over 24 hours was also recorded.

Incidence of postoperative side effects were also assessed, e.g. nausea, vomiting, sedation (assessed by numeric scale of 0-3 where $0=$ fully awake, $1=$ patient somnolent but responsive to command, $2=$ patients somnolent but responsive to tactile stimuli, $3=$ patients somnolent but responsive to painful stimuli only.), respiratory depression, dizziness, pruritus, urinary retention and hallucination were recorded.

The data was compiled systematically in Microsoft excel 2010 \& analysed using IBM SPSS version 23. Parametric data were expressed in mean \pm standard deviation (SD). Student's independent t-test was used for parametric data. For non-parametric data, chi-square test was used. $P$ value of less than 0.05 was considered as statistically significant.

\section{Results}

Data was collected from 100 patients included in the study.

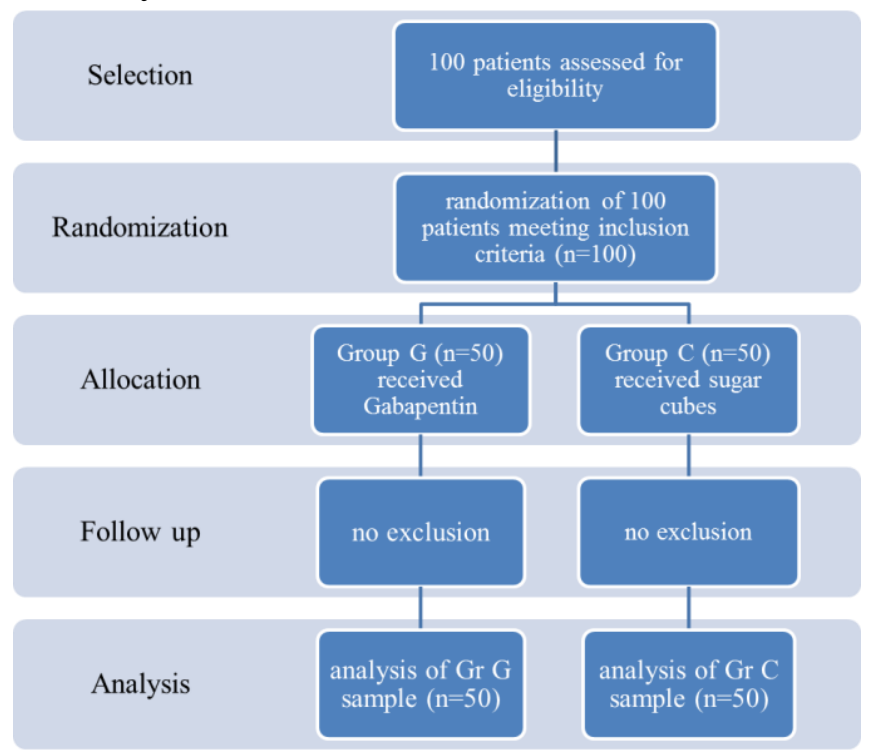

Table 1. Demographic data of patients

\begin{tabular}{|l|c|c|c|}
\hline Variable & Gr C & Gr G & $\begin{array}{c}\text { P } \\
\text { value }\end{array}$ \\
\hline Age(yrs.) & $51.06 \pm 5.63$ & $50.74 \pm 5.43$ & 0.77 \\
\hline Weight (kg) of & $51.3 \pm 4.94$ & $50.32 \pm 3.85$ & 0.27 \\
\hline $\begin{array}{l}\text { Duration } \\
\text { surgery(min) }\end{array}$ & $55 \pm 6.05$ & $55.68 \pm 4.68$ & 0.53 \\
\hline $\begin{array}{l}\text { Duration of motor } \\
\text { block (min) }\end{array}$ & $83.14 \pm 3.42$ & $83.66 \pm 3.37$ & 0.44 \\
\hline $\begin{array}{l}\text { Duration of sensory } \\
\text { block (min) }\end{array}$ & $108.62 \pm 3.89$ & $108.56 \pm 4.13$ & 0.94 \\
\hline $\begin{array}{l}\text { ASA Physical status } \\
\text { I/II }\end{array}$ & $28 / 22$ & $27 / 23$ & 0.84 \\
\hline
\end{tabular}

No significant difference was observed between the two groups in terms of age, body weight, duration of surgery, duration of motor block, duration of sensory block and ASA physical status. (Table 1). 
Table 2 Pulse rate

\begin{tabular}{|l|c|c|c|}
\hline $\begin{array}{l}\text { Time in } \\
\text { hrs. }\end{array}$ & $\begin{array}{c}\text { Gr C } \\
\text { Mean } \pm \text { SD }\end{array}$ & Gr G Mean \pm SD & P Value \\
\hline 0 & $119.08 \pm 8.57$ & $104.18 \pm 7.4$ & $<0.001$ \\
\hline 2 & $114.96 \pm 9.49$ & $99.36 \pm 6.53$ & $<0.001$ \\
\hline 4 & $106.4 \pm 8.74$ & $90.3 \pm 5.63$ & $<0.001$ \\
\hline 6 & $102.18 \pm 7.38$ & $88.66 \pm 6.70$ & $<0.001$ \\
\hline 8 & $99.82 \pm 7.48$ & $84.96 \pm 4.99$ & $<0.001$ \\
\hline 12 & $95.54 \pm 7.46$ & $82.24 \pm 6.35$ & $<0.001$ \\
\hline 18 & $91.44 \pm 6.26$ & $80.66 \pm 5.97$ & $<0.001$ \\
\hline 24 & $89.94 \pm 6.38$ & $77.92 \pm 5.95$ & $<0.001$ \\
\hline
\end{tabular}

Table 2 shows the comparison of pulse rate between both groups. Pulse rate is significantly lower at all times in Group G as compared to Group C.

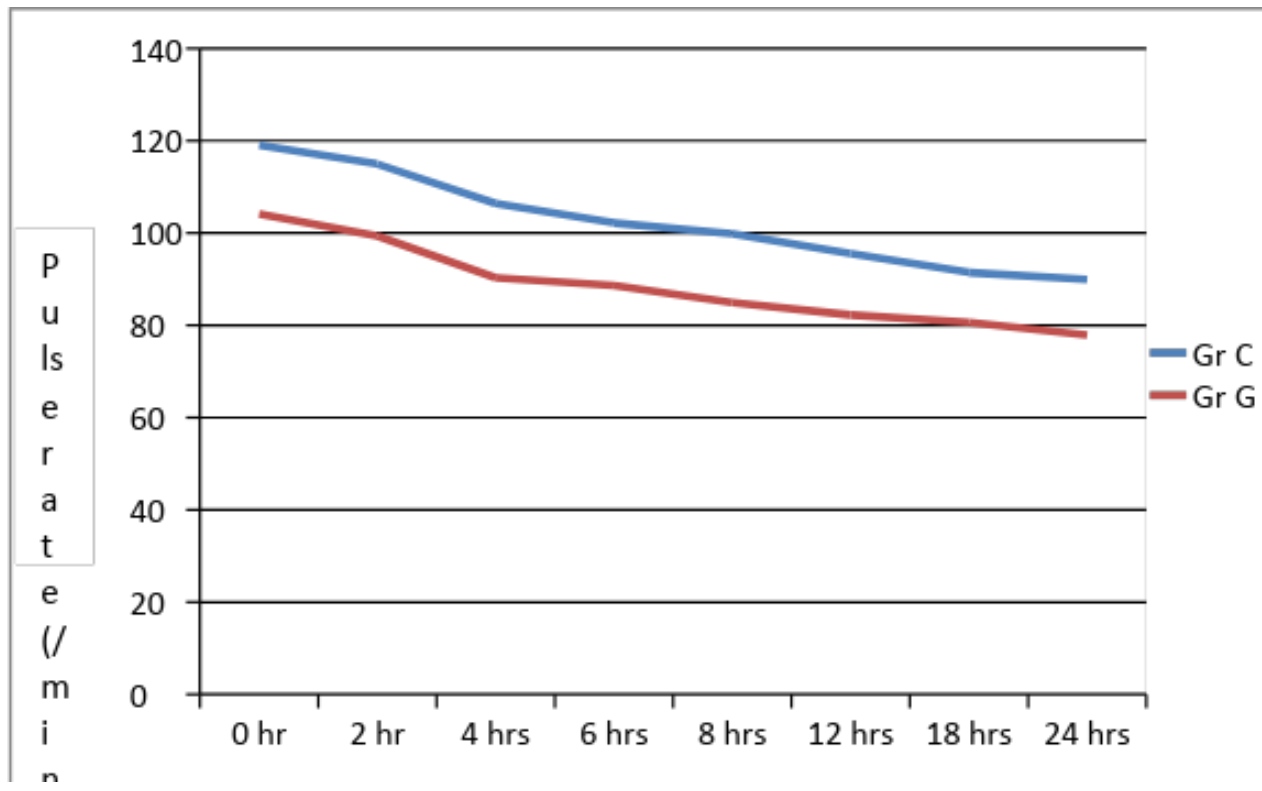

Figure 2: Pulse rate

Table 3 Systolic blood pressure

\begin{tabular}{|l|c|c|c|}
\hline Time in hrs. & $\begin{array}{c}\text { Gr C } \\
\text { Mean } \pm \text { SD }\end{array}$ & $\begin{array}{c}\text { Gr G } \\
\text { Mean } \pm \text { SD }\end{array}$ & P Value \\
\hline 0 & $113.76 \pm 10.25$ & $113.68 \pm 10.17$ & 0.96 \\
\hline 2 & $135.4 \pm 7.00$ & $127.36 \pm 5.7$ & $<0.001$ \\
\hline 4 & $129.36 \pm 6.21$ & $122.92 \pm 4.97$ & $<0.001$ \\
\hline 6 & $128.26 \pm 6.27$ & $122.84 \pm 4.03$ & $<0.001$ \\
\hline 8 & $127.38 \pm 7.81$ & $121.44 \pm 3.28$ & $<0.001$ \\
\hline 12 & $127.02 \pm 4.72$ & $121.24 \pm 4.86$ & $<0.001$ \\
\hline 18 & $126.92 \pm 5.73$ & $120.8 \pm 2.90$ & $<0.001$ \\
\hline 24 & $125.44 \pm 4.55$ & $120.56 \pm 3.69$ & $<0.001$ \\
\hline
\end{tabular}

Table 3 shows the comparison of systolic blood pressure over 24 hours in between groups. The difference between the groups was non-significant at baseline. At all other times SBP was statistically lower in Group G than Group C. 


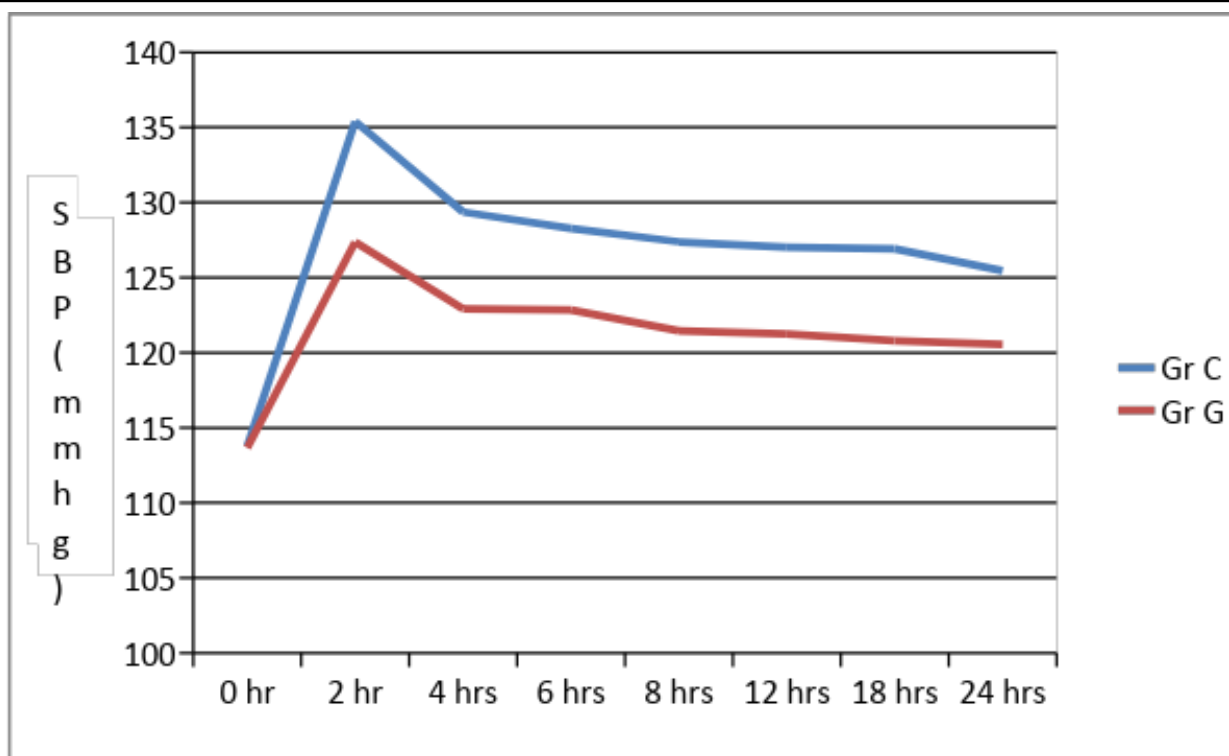

Figure 3: Systolic blood pressure

Table 4 Diastolic blood pressure

\begin{tabular}{|l|c|c|c|}
\hline Time in hrs & $\begin{array}{c}\text { Gr C } \\
\text { Mean } \pm \text { SD }\end{array}$ & $\begin{array}{c}\text { Gr G } \\
\text { Mean } \pm \text { SD }\end{array}$ & P Value \\
\hline 0 & $91.92 \pm 4.81$ & $75.4 \pm 4.09$ & $<0.001$ \\
\hline 2 & $90.44 \pm 4.00$ & $85.44 \pm 4.04$ & $<0.001$ \\
\hline 4 & $85.42 \pm 3.90$ & $82.72 \pm 4.47$ & 0.002 \\
\hline 6 & $84.98 \pm 3.83$ & $82.54 \pm 4.09$ & 0.003 \\
\hline 8 & $84.6 \pm 3.83$ & $82 \pm 3.14$ & $<0.001$ \\
\hline 12 & $84 \pm 3.60$ & $81.46 \pm 4.05$ & 0.001 \\
\hline 18 & $83.12 \pm 3.61$ & $80.7 \pm 4.17$ & 0.002 \\
\hline 24 & $82.58 \pm 3.20$ & $80.12 \pm 3.85$ & $<0.001$ \\
\hline
\end{tabular}

Table 4 compares that the diastolic blood pressure (DBP) of patients at various times in both groups. It was significantly lower at all times in Group G.

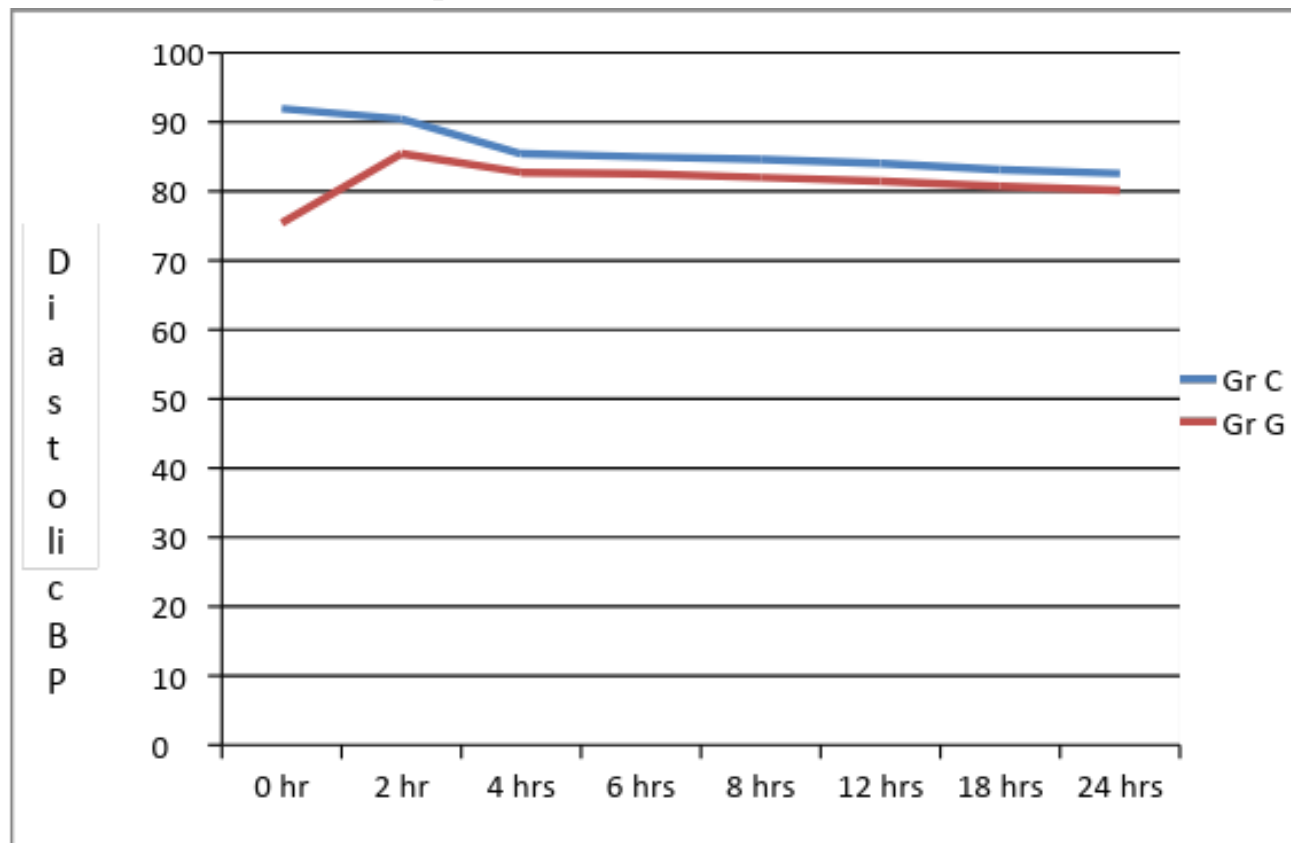

Figure 4: Diastolic blood pressure 
Table $5 \mathrm{SpO}_{2}$

\begin{tabular}{|l|c|c|c|}
\hline Time in hrs. & Gr C $($ Mean \pm SD $)$ & Gr G $($ Mean \pm SD $)$ & P Value \\
\hline 0 & $99.6 \pm .57$ & $99.42 \pm .70$ & 0.16 \\
\hline 2 & $99.42 \pm .64$ & $99.3 \pm .67$ & 0.36 \\
\hline 4 & $99.4 \pm .53$ & $99.46 \pm .73$ & 0.64 \\
\hline 6 & $99.52 \pm .54$ & $99.54 \pm .57$ & 0.85 \\
\hline 8 & $99.46 \pm .54$ & $99.54 \pm .57$ & 0.48 \\
\hline 12 & $99.46 \pm .54$ & $99.54 \pm .57$ & 0.48 \\
\hline 24 & $99.42 \pm .60$ & $99.54 \pm .57$ & 0.31 \\
\hline
\end{tabular}

Table 5 shows that the comparison of $\mathrm{SPO}_{2}$ in between two groups. It was non-significant at all times.

Table 6 Postoperative pain score (VAS)

\begin{tabular}{|l|c|c|c|}
\hline Time in hrs. & $\begin{array}{c}\text { Gr C } \\
\text { Mean } \pm \text { SD }\end{array}$ & $\begin{array}{c}\text { Gr G } \\
\text { Mean } \pm \text { SD }\end{array}$ & P Value \\
\hline 0 & $11.26 \pm 2.13$ & $8.62 \pm 2.70$ & $<0.001$ \\
\hline 2 & $36.2 \pm 4.14$ & $27.52 \pm 2.71$ & $<0.001$ \\
\hline 4 & $31.06 \pm 3.19$ & $20.36 \pm 3.04$ & $<0.001$ \\
\hline 6 & $32.84 \pm 2.83$ & $23.04 \pm 2.51$ & $<0.001$ \\
\hline 8 & $37.5 \pm 4.78$ & $25.54 \pm 4.87$ & $<0.001$ \\
\hline 12 & $27.48 \pm 3.74$ & $24.48 \pm 5.34$ & 0.002 \\
\hline 18 & $29.82 \pm 6.22$ & $22.5 \pm 7.12$ & $<0.001$ \\
\hline 24 & $29.26 \pm 4.48$ & $23.22 \pm 5.74$ & $<0.001$ \\
\hline
\end{tabular}

The mean VAS scores of all patients in each group at various times has been compared in lower at all times in Group $\mathrm{G}$ as compared to Group C.

Table 6. The mean VAS scores were significantly

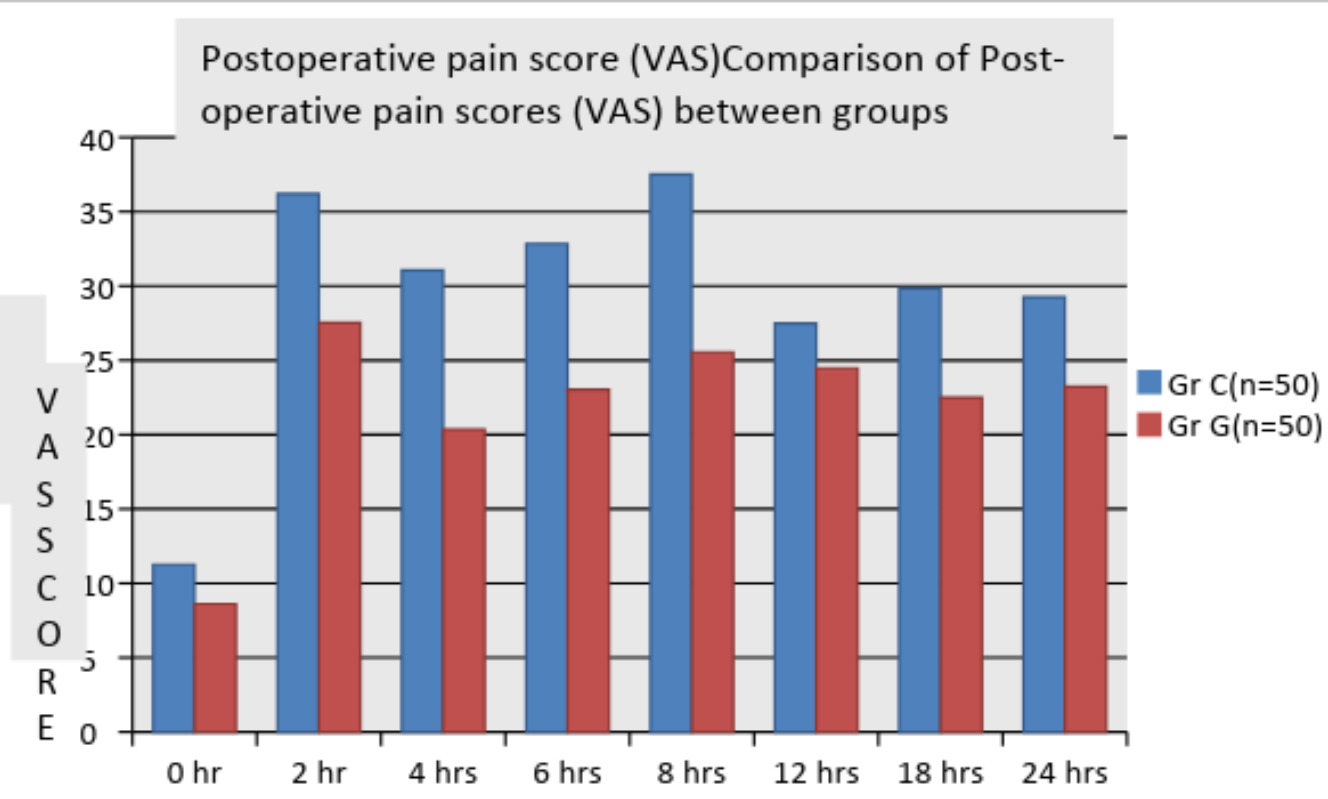

Figure 5 Comparison between VAS score. 
Table 7 Postoperative Tramadol consumption

\begin{tabular}{|l|c|c|c|}
\hline Groups & Gr C $($ Mean \pm SD) & Gr G $($ Mean \pm SD) & P value \\
\hline Postoperative tramadol consumption & $98.9 \pm 14.09$ & $51.27 \pm 14.73$ & $<0.001$ \\
\hline Postoperative sedation score & $1.74 \pm 0.52$ & $2.78 \pm 0.67$ & $<0.001$ \\
\hline
\end{tabular}

Postoperative consumption of tramadol and sedation scores have been compared in Table 7 . The mean tramadol requirement was $51.27 \pm 14.73$ $\mathrm{mg}$ in group $\mathrm{G}$ while it was $98.9 \pm 14.09 \mathrm{mg}$ in group $\mathrm{C}$, with a $\mathrm{p}$ value of $<0.001$ which was

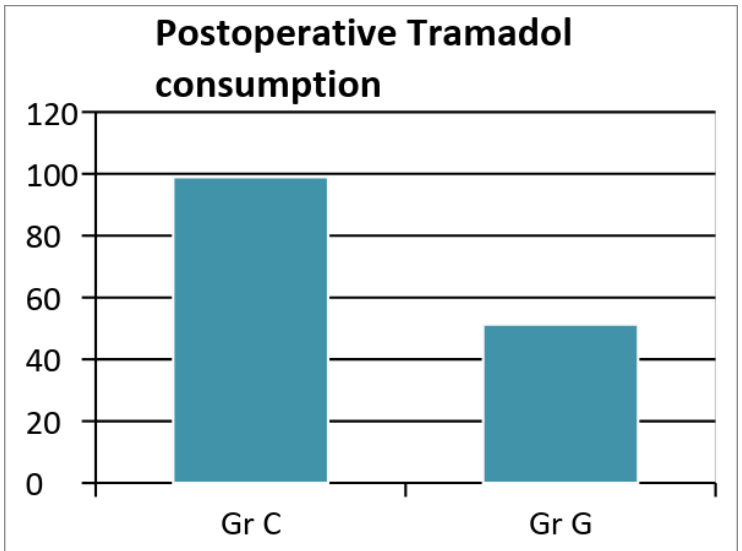

Figure 6. Tramadol consumption highly significant statistically. The mean sedation score in group $\mathrm{G}$ was $2.78 \pm 0.67$ while that in group $C$ was $1.74 \pm 0.52$. Sedation scores were significantly higher in group $\mathrm{G}$ than group $\mathrm{C}$.

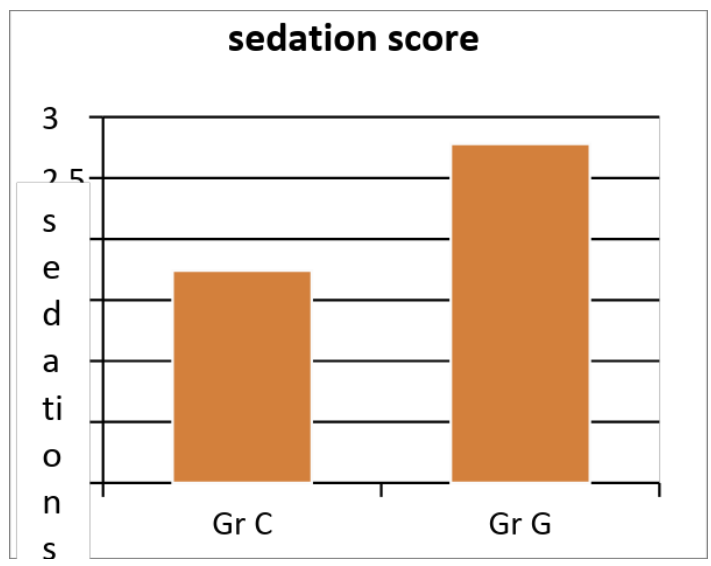

Figure 7. Sedation score

Table 8 Nausea and Vomiting

\begin{tabular}{|l|c|c|}
\hline Groups & Nausea (\%) & Vomiting (\%) \\
\hline Gr C & $5(10 \%)$ & $2(4 \%)$ \\
\hline Gr G & $13(26 \%)$ & $8(16 \%)$ \\
\hline P value & 0.066 & 0.092 \\
\hline
\end{tabular}

Table 8 shows the incidence of nausea and and $8(16 \%)$ in group $\mathrm{G}$. There was no statistical vomiting among the two groups. There were 5 $(10 \%)$ incidents of nausea and $2(4 \%)$ incidents of vomiting in group $\mathrm{C}$ while they were $13(26 \%)$ significance in the incidence of nausea and vomiting among the two groups.

Table 9 Adverse events

\begin{tabular}{|l|c|c|c|}
\hline Variable & Gr C & Gr G & P value \\
\hline Dizziness & $2(4 \%)$ & $6(12 \%)$ & 0.269 \\
\hline Dry mouth & 0 & 0 & - \\
\hline Urinary retention & $4(8 \%)$ & $2(4 \%)$ & 0.678 \\
\hline Hallucination & 0 & $2(4 \%)$ & 0.495 \\
\hline
\end{tabular}

The incidence of adverse events has been shown in Table 9. None of the patients in group $\mathrm{C}$ had hallucinations but 2 patients in group $\mathrm{G}$ hallucinated (4\%). 2 in group C (4\%) and 6 in group G (12\%) felt dizzy. 4 (8\%) patients in group $\mathrm{C}$ and 2 (4\%) patients in group G had urinary retention. None of the patients in study groups had dry mouth in 24 hours of study period.

\section{Discussion}

A number of mechanisms may be involved in the actions of gabapentin ${ }^{(45)}$. Possible pharmacologic targets of gabapentin are selective activation of the hetero-dimeric $\mathrm{GABA}_{\mathrm{B}}$ receptors which consist of $\mathrm{GABA}_{\mathrm{B} 1 \mathrm{a}}$ and $\mathrm{GABA}_{\mathrm{B} 2}$ subunits $^{(46,47)}$; enhancement of the $N$-methyl-D-aspartate (NMDA) current at GABAergic interneurons ${ }^{(48)}$; 
blocking alpha-amino-3-hydroxy-5-methyl-4isoxazolepropionic acid (AMPA) receptor mediated transmission in the spinal cord ${ }^{(49,50)}$; binding to the $\mathrm{L}$ Alpha amino acid transporter ${ }^{(51,52)}$; activating adenosine triphosphate sensitive $\mathrm{K}^{+}\left(\mathrm{K}_{\text {ATP }}\right)$ channels ${ }^{(53,54)}$; activating hyperpolarization-activated cation current (Ih) channels ${ }^{(55,56)}$ and modulating $\mathrm{Ca}^{2+}$ current by selectively binding to $\left[{ }^{3} \mathrm{H}\right]$ gabapentin (a radioligand), the alpha 2 delta subunit of voltagedependent $\mathrm{Ca}^{2+}$ channels (VGCCs) ${ }^{(57,58,59)}$. Currently, VGCC is the most likely antinociceptive target of gabapentin. The proposed consequence of gabapentin binding to the alpha 2 delta subunit is a reduction in neurotransmitter release and hence a decrease in neuronal hyperexcitability. Gabapentin has been shown to inhibit the evoked release of glutamate ${ }^{(60)}$, aspartate ${ }^{(61)}$, substance $\mathrm{P}$, and calcitonin gene-related peptide (CGRP) (62) from the spinal cord of rats. Interestingly, recent studies have demonstrated that the descending noradrenergic system, spinal $\square_{2}$ adrenergic receptors and an intact spino-bulbospinal circuit are crucial elements influencing the analgesic effects of gabapentin in addition to alpha $_{2}$ delta interaction ${ }^{(63,64)}$.

Various studies have proven the efficacy of gabapentin preemptive analgesia as opioid sparing agent. In 2001, Werner MU et al. first showed the hopes of light in the field of post-operative analgesia that gabapentin has significant role in acute inflammatory pain in human beings ${ }^{(65)}$. Gregg AK et al. established role of gabapentin in post-operative analgesia as premedication in laparoscopic cholecystectomy ${ }^{(66)}$.

Dirks $J$ et al. concluded that in gabapentin group, 24 hour post-surgery morphine consumption was remarkably less than the placebo group (67). Fassoulaki A et al. concluded that mexiletine $600 \mathrm{mg} /$ day, gabapentin $1200 \mathrm{mg} /$ day both reduced the postoperative analgesic requirements and particularly gabapentin reduced pain after movement in patients operated for carcinoma breast ${ }^{(68)}$.Dierking $K$ et al. found $32 \%$ reduction in morphine consumption in patients given with
$1200 \mathrm{mg}$ of gabapentin in 1 hour preoperatively and then $600 \mathrm{mg}$ in $8,12,24$ hours after the initial dose. ${ }^{(69)}$.

Pandey $C K$ et al. concluded that pre-emptive use of gabapentin (as compared to tramadol) significantly decreases postoperative pain and fentanyl consumption in laparoscopic cholecystectomy ${ }^{(70)} \&$ in lumbar discoidectomy ${ }^{(71)}$. Turan $A$ et al. concluded that preoperative oral gabapentin decreases pain scores in early postoperative period and postoperative morphine consumption in spinal surgery ${ }^{(72)}$. Rorarius $M G F$ et al. concluded that gabapentin reduced the need for additional postoperative pain treatment (PCA boluses of 50 microgram of fentanyl) by $40 \%$ during the first 20 postoperative hours compared to placebo controlled group ${ }^{(73)}$.

Pandey CK, Navkar DV, Giri PJ et al compared different pre-emptive doses of gabapentin for postoperative pain relief after single-level lumbar discectomy and its effect on fentanyl consumption $\&$ concluded that increasing the dose of gabapentin from $600 \mathrm{mg}$ to $1200 \mathrm{mg}$ did not decreases the VAS score nor did the increasing dose of gabapentin significantly decreases fentanyl consumption. Thus, gabapentin $600 \mathrm{mg}$ is the optimal dose for postoperative pain relief following lumbar discectomy ${ }^{(74)}$.

Turan A, Kaya G, Apfel CC et al demonstrated gabapentin as a good adjuvant for postoperative pain management in patients undergoing different lower limb procedures ${ }^{(75)}$.

Al-Mujadi $H$ et al. gabapentin $1200 \mathrm{mg}$ orally two hours prior to induction of anaesthesia to patients undergoing selective thyroidectomy significantly decreased pain scores and morphine consumption in the postoperative period ${ }^{(76)}$.

Findings of the present study lend support to the observations by Pandey et al and also corroborates with the findings of other workers.

Gabapentin has been reported as an anxiolytic agent in previous studies ${ }^{(77-80)}$. It was effective in treating anxiety associated with panic disorders. $(78,79,81)$ De-Paris et al. ${ }^{(81)}$ demonstrated that gabapentin attenuates anxiety associated with 
simulated public speaking in volunteers. This disorder may be related to the preoperative anxiety state. The interest in using gabapentin preoperatively to decrease preoperative anxiety is due to its limited side effects in comparison to other standard mood-stabilizing agents. Moreover, gabapentin seems anxiolytic without exerting amnesic effects ${ }^{(82)}$. However, additional study is necessary to fully validate these promising aspects of gabapentin pharmacology.

Reducing preoperative anxiety with gabapentin may have contributed to the improved postoperative pain and to the reduced opioid use since there is a possible association between preoperative anxiety and postoperative pain ${ }^{(83,84)}$. But, whether preoperative anxiolysis without coping behaviour and preoperative information has an impact on the postoperative pain response and morphine requirements remains controversial (84)

The use of gabapentin might be limited by its previously reported side effects, e.g., dizziness, somnolence, confusion, and ataxia ${ }^{(85)}$. However, the incidences of such adverse effects were not significant in the present study.

\section{Conclusion}

We conclude that Gabapentin, when used as a preemptively, provides greater degree of analgesia with opioid sparing effect. It reduces postoperative pain and analgesic consumption \& also provides anxiolysis.

\section{References}

1. Brown JG. Systemic opioid analgesia for postoperative pain management. Anesthesiology Clinics of North America. 1989 Mar 1;7(1):51-62.

2. Reuben SS, Vieira P, Faruqi S, Verghis A, Kilaru PA, Maciolek H. Local Administration of Morphine for Analgesia after Iliac Bone Graft Harvest: Retracted. Anesthesiology: The Journal of the American Society of Anesthesiologists. 2001 Aug 1;95(2):390-4.
3. Opioid Analgesics and Antagonists: Essentials of Medical Pharmacology, $4^{\text {th }}$ edition update reprint: K.D. Tripathi; Jaypee Brothers Medical Publishers (P) Ltd. 2001: 432-49.

4. Barber A, Bartoszyk GD, Greiner HE, Mauler F, Murray RD, Seyfried CA, Simon M, Gottschlich R, Harting J, Lues I. Central and peripheral actions of the novel $\kappa$-opioid receptor agonist, EMD 60400. British journal of pharmacology. 1994 Mar 1;111(3):843-51.

5. Hiller A, Silvanto M, Savolainen S, Tarkkila P. Propacetamol and diclofenac alone and in combination for analgesia after elective tonsillectomy. Acta anaesthesiologica scandinavica. 2004 Oct;48(9):1185-9.

6. Yee J, Brown C, Allison C, Wildman K. Analgesia from intramuscular ketorolac tromethamine compared to morphine (ms) in severe pain following major surgery. inclinical pharmacology \& therapeutics 1985 Jan 1 (Vol. 37, No. 2, pp. 239-239).

7. Nonopioid analgesic and Nonsteroidal Antiinflammatory drugs: Essentials of Medical Pharmacology, $4^{\text {th }}$ edition updated reprint: K.D.Tripathi; Jaypee Brothers Medical Publishers(P) Ltd.2001:450-67.

8. Burkle H, Gogarten W, Van Aken $\mathrm{H}$. Intravenous non-opioid analgesics in anaesthesia-the role of paracetamol, metamizol, tenoxicam and parecoxib in the perioperative treatment of acute pain. Anasthesiologie \& Intensivmedizin. 2003 Apr 1;44(4):311-20.

9. Barden J, Edwards JE, McQuay HJ, Moore RA. Oral valdecoxib and injected parecoxib for acute postoperative pain: a quantitative systematic review. BMC anesthesiology. 2003 Dec;3(1):1.

10. Groudine SB, Fisher HA, Kaufman RP, Patel MK, Wilkins LJ, Mehta SA, Lumb PD. Intravenous lidocaine speeds the return of bowel function, decreases 
postoperative pain, and shortens hospital stay in patients undergoing radical retropubic prostatectomy. Anesthesia \& Analgesia. 1998 Feb 1;86(2):235-9.

11. Carli F, Trudel JL, Belliveau P. The effect of intraoperative thoracic epidural anesthesia and postoperative analgesia on bowel function after colorectal surgery. Diseases of the colon \& rectum. 2001 Aug 1;44(8):1083-9

12. Hamunen K. Ventilatory effects of morphine, pethidine and methadone in children. BJA: British Journal of Anaesthesia. 1993 Apr 1;70(4):414-8.

13. Szczeklik A, Stevenson DD. Aspirininduced asthma: advances in pathogenesis, diagnosis, and management. Journal of Allergy and Clinical Immunology. 2003 May 1;111(5):913-21.

14. Strom BL, Berlin JA, Kinman JL, Spitz PW, Hennessy S, Feldman H, Kimmel S, Carson JL. Parenteral ketorolac and risk of gastrointestinal and operative site bleeding: a postmarketing surveillance study. Jama. 1996 Feb 7;275(5):376-82.

15. Cheng HF, Harris RC. Cyclooxygenases, the kidney, and hypertension. Hypertension. 2004 Mar 1;43(3):525-30.

16. Clark DW, Layton D, Shakir SA. Do some inhibitors of COX-2 increase the risk of thromboembolic events?. Drug Safety. 2004 Jun 1;27(7):427-56.

17. Giebler RM, Scherer RU, Peters J. Incidence of neurologic complications related to thoracic epidural catheterization. Anesthesiology: The Journal of the American Society of Anesthesiologists. 1997 Jan 1;86(1):55-63.

18. Vandermeulen EP, Van Aken $H$, Vermylen J. Anticoagulants and spinalepidural anesthesia. Anesthesia \& Analgesia. 1994 Dec 1;79(6):1165-77.

19. Bach S, Noreng MF, Tjéllden NU. Phantom limb pain in amputees during the first 12 months following limb amputation, after preoperative lumbar epidural blockade. Pain. 1988 Jun 1;33(3):297-301.

20. Jahangiri M, Jayatunga AP, Bradley JW, Dark CH. Prevention of phantom pain after major lower limb amputation by epidural infusion of diamorphine, clonidine and bupivacaine. Annals of the Royal College of Surgeons of England. 1994 Sep;76(5):324.

21. Schug SA, Burrell R, Payne J, Tester P. Pre-emptive epidural analgesia may prevent phantom limb pain. Regional anesthesia. 1995;20(3):256.

22. Katz J, Jackson M, Kavanagh BP, Sandler AN. Acute pain after thoracic surgery predicts long-term post-thoracotomy pain. The Clinical journal of pain. 1996 Mar 1;12(1):50-5.

23. Perkins FM, Kehlet H. Chronic pain as an outcome of surgeryA review of predictive factors. Anesthesiology: The Journal of the American Society of Anesthesiologists. 2000 Oct 1;93(4):1123-33.

24. Poobalan AS, Bruce J, Smith WC, King PM, Krukowski ZH, Chambers WA. A review of chronic pain after inguinal herniorrhaphy. The Clinical Journal of Pain. 2003 Jan 1;19(1):48-54.

25. Backonja M, Beydoun A, Edwards KR. Gabapentin for the symptomatic treatment of painful neuropathy in patients with diabetes mellitus: a randomized controlled trial. JAMA (1998); 280:1831-6.

26. Donovan-Rodriguez T, Dickenson AH, Urch CE. Gabapentin normalizes spinal neuronal responses that correlate with behavior in a rat model of cancer-induced bone pain. Anesthesiology (2005); 102:132-40.

27. Gottrup H, Juhl G, Kristensen AD, et al. Chronic oral gabapentin reduces elements of central sensitization in human experimental hyperalgaesia. Anesthesiology (2004) ;101:1400-8. 
28. Hahn K, Arendt G, Braun JS, et al. A placebo-controlled trial of gabapentin for painful HIV-associated sensory neuropathies. J Neurol (2004) 251:1260-6.

29. Mellick LB, Mellick GA. Successful treatment of reflex sympathetic dystrophy with gabapentin. Am J Emerg Med (1995); 13:96.

30. Nicholson B. Gabapentin use in neuropathic pain syndromes. Acta Neurol Scand (2000) ;101:359-71.

31. Rosenberg JM, Harrell C, Ristic H, Werner RA, de Rosayro AM. The effect of gabapentin on neuropathic pain. Clin $\mathrm{J}$ Pain (1997); 13:251-5.

32. Werner MU, Perkins FM, Holte K, Pedersen JL, Kehlet $H$. Effects of gabapentin in acute inflammatory pain in humans. Reg Anesth Pain Med (2001) ;26:322-8.

33. Dirks J, Fredensborg BB, Christensen D, et al. A randomized study of the effects of single dose gabapentin versus placebo on postoperative pain and morphine consumption after mastectomy. Anesthesiology 2002; 97: 560-4.

34. Jun JH, Yaksh TL: The effect of intrathecal gabapentin and 3-isobutyl gamma-aminobutyric acid on the hyperalgesia observed after thermal injury in the rat. Anesth Analg 1998; 86: 348-54.

35. Chapman V, Suzuki R, Chamarette HL, Rygh IJ, Dickenson AH: Effects of systemic carbamazepine and gabapentin on spinal neuronal responses in spinal nerve ligated rats. Pain 1998; 75: 261-72.

36. Field MJ, Holloman EF, McCleary S, Singh L: Evaluation of gabapentin and S(+)-3-isobutylgaba in a rat model of postoperative pain. J. Pharmacol Exp Ther 1997; 282: 1242-6.

37. Patel S, Naeem S, Kesingland A, Capogna M, Urban L, Fox A : The effects of GABA $b$ agonists and gabapentin on mechanical hyperalgesia in models of neuropathic and inflammatory pain in the rat. Pain 2001; 90: 217-26.

38. Gilron I, Orr E, Tu D, O’Neill JP, Zamora JE, Bell AC. A placebo-controlled randomized clinical trial of perioperative administration of gabapentin, rofecoxib and their combination for spontaneous and movement-evoked pain after abdominal hysterectomy. Pain (2005); 113:191-200.

39. Rorarius MGF, Mennander S, Suominen $\mathrm{P}$, et al. Gabapentin for the prevention of postoperative pain after vaginal hysterectomy. Pain (2004) 110:175-81.

40. Fassoulaki A, Patris K, Sarantopoulos C, Hogan Q. The analgesic effect of gabapentin and mexiletine after breast surgery for cancer. Anesth Analg (2002); 95:985-91.

41. Pandey CK, Priye S, Singh S, Singh U, Singh RB, Singh PK. Preemptive use of gabapentin significantly decreases postoperative pain and rescue analgesic requirement in laparoscopic cholecystectomy. Can J Anaesth (2004); 51:358-63.

42. Turan A, Karamanlolu B, Memi D, Usar P, Pamukçu Z, Türe M. The analgesic effects of gabapentin after total abdominal hysterectomy. Anesth Analg (2004); 98:1370-3.

43. Pandey CK, Sahay S, Gupta D, et al. Preemptive gabapentin decreases postoperative pain after lumbar discoidectomy. Can J Anesth (2004) ;51:986-9.

44. Radhakrishnan M, Bithal PK, Chaturvedi A. Effect of preemptive gabapentin on postoperative pain relief and morphine consumption following lumbar laminectomy and discectomy. J Neurosurg Anesthesiol (2005); 17:125-8.

45. Bonhaus DW, Loo C, Secchi R, et al. Effects of the $\mathrm{GABA}_{\mathrm{B}}$ receptor antagonist CGP 55845 on the anticonvulsant and anxiolytic actions of gabapentin (XIVth World Congress of Pharmacology, San 
Francisco: ASPET). Pharmacologist (2002) ;44:A100.

46. Bertrand S, Ng GY, Purisai MG. The anticonvulsant, antihyperalgesic agent gabapentin is an agonist at brain gammaaminobutyric acid type $B$ receptors negatively coupled to voltage-dependant calcium channels. J Pharmacol Exp Ther (2001) ;298:15-24.

47. Ng GY, Bertrand S, Sullivan R, et al. gamma-aminobutyric acid type B receptors with specific heterodimer composition and postsynaptic actions in hippocampal neurons are targets of anticonvulsant gabapentin action. Mol Pharmacol (2001);59:144-52.

48. Gu Y, Huang LY. Gabapentin potentiates $\mathrm{N}$-methyl-D-aspartate receptor mediated currents in rat GABAergic dorsal horn neurons. Neurosci Lett (2002); 324:17780.

49. Chizh BA, Scheede M, Schlutz H. Antinociception and (R,S)-alpha-amino-3hydoxy-5-methyl-4-isoxazole propionic acid antagonism by gabapentin in the rat spinal cord in vivo. Naunyn Schmiedebergs Arch Pharmacol (2000); 362:197-200.

50. Shimoyama M, Shimoyama N, Hori Y. Gabapentin affects glutamatergic excitatory neurotransmission in the rat dorsal horn. Pain (2000); 85:405-14.

51. Gidal BE, Radulovic LL, Kruger S, Rutecki P, Pitterle M, Bockbrader HN. Inter- and intra-subject variability in gabapentin absorption and absolute bioavailability. Epilepsy Res (2000); 40:123-7.

52. Su TZ, Lunney E, Campbell G. Transport of gabapentin, a -amino acid drug, by system 1 alpha-amino acid transporters: a comparative study in astrocytes, synaptosomes, and $\mathrm{CHO}$ cells. J Neurochem (1995) ;64:2125-31.
53. Freiman TM, Kukolja J, Heinemeyer J, et al. Modulation of $\mathrm{K}^{+}$-evoked $\left[{ }^{3} \mathrm{H}\right]$ noradrenaline release from rat and human brain slices by gabapentin: involvement of KATP channels. Naunyn Schmiedebergs Arch Pharmacol (2001); 363:537-42.

54. Mixcoatl-Zecuatl T, Medina-Santillán R, Reyes-Garcia G, Vidal-Cantú GC, Granados-Soto V. Effect of $\mathrm{K}+$ channel modulators on the antiallodynic effect of gabapentin. Eur J Pharmacol (2004); 484:201-8.

55. Surges R, Freiman TM, Feuerstein TJ. Gabapentin increases the hyperpolarization-activated cation current Ih in rat CA1 pyramidal cells. Epilepsia (2003) ;44:150-6.

56. Surges R, Freiman TM, Feuerstein TJ. Input resistance is voltage dependent due to activation of Ih channels in rat CA1 pyramidal cells. J Neurosci Res (2004); 76:475-80.

57. Fink K, Dooley DJ, Meder WP, et al. Inhibition of neuronal $\mathrm{Ca}^{2+}$ influx by gabapentin and pregabalin in the human neocortex. Neuropharmacology (2002); 42:229-36.

58. Gee NS, Brown JP, Dissanayake VU, Offord J, Thurlow R, Woodruff GN. The novel anticonvulsant drug, gabapentin (Neurontin), binds to the alpha 2 delta subunit of a calcium channel. J Biol Chem (1996); 271:5768-76.

59. Stefani A, Spadoni F, Bernardi G. Gabapentin inhibits calcium currents in isolated rat brain neurons. Neuropharmacology (1998) ;37:83-91.

60. Coderre TJ, Kumar N, Lefebvre CD, Yu JSC. Evidence that gabapentin reduces neuropathic pain by inhibiting the spinal release of glutamate. J Neurochem (2005); 94:1131-9.

61. Feng Y, Cui M, Willis WD. Gabapentin markedly reduces acetic acid-induced 
visceral nociception. Anesthesiology (2003); 98:729-33.

62. Fehrenbacher JC, Taylor CP, Vasko MR. Pregabalin and gabapentin reduce release of substance $\mathrm{P}$ and CGRP from rat spinal tissues only after inflammation or activation of protein kinase C. Pain (2003) ;105:133-41.

63. Suzuki R, Rahman W, Rygh LJ, Webber M, Hunt SP, Dickenson AH. Spinalsupraspinal serotonergic circuits regulating neuropathic pain and its treatment with gabapentin. Pain (2005) ;117:292-303.

64. Tanabe M, Takasu K, Kasuya N, Shimizu $\mathrm{S}$, Honda M, Ono H. Role of descending noradrenergic system and spinal alpha2adrenergic receptors in the effects of gabapentin on thermal and mechanical nociception after partial nerve injury in the mouse. Br J Pharmacol (2005); 144:70314.

65. Werner MU, Perkins FM, Holte K, Pedersen JL, Kehlet H. Effects of gabapentin in acute inflammatory pain in humans. Reg Anesth Pain Med (2001); 26:322-8.

66. Gregg AK, Francis S, Sharpe P, Rowbotham DJ. Analgesic effect of gabapentin premedication in laparoscopic cholecystectomy: a randomized doubleblind placebo controlled trial. Br. J. Anesth 2001; 87:174P(abstract).

67. Dirks J, Fredensborg BB, Christensen D, Fomsgaard JS, Flyger H, Dahl JB. A randomized study of the effects of singledose gabapentin versus placebo on postoperative pain and morphine consumption after mastectomy. Anesthesiology (2002) ; 97:560-4.

68. Fassoulaki A, Patris K, Sarantopoulos C, Hogan Q. The analgesic effect of gabapentin and mexiletine after breast surgery for cancer. Anesth Analg (2002); 95:985-91.
69. Dierking G, Duedahl TH, Rasmussen ML, et al. Effects of gabapentin on postoperative morphine consumption and pain after abdominal hysterectomy: a randomized, double-blind trial. Acta Anaesthesiol Scand (2004) ;48:322-7.

70. Pandey CK, Priye S, Singh S, Singh U, Singh RB, Singh PK. Preemptive use of gabapentin significantly decreases postoperative pain and rescue analgesic requirement in laparoscopic cholecystectomy. Can J Anaesth (2004); 51:358-63.

71. Pandey CK, Sahay S, Gupta D, et al. Preemptive gabapentin decreases postoperative pain after lumbar discoidectomy. Can J Anesth (2004) ;51:986-9.

72. Turan A, Karamanlioglu B, Memis D, et al. Analgesic effects of gabapentin after spinal surgery. Anesthesiology (2004) 100:935-8.

73. Rorarius MGF, Mennander S, Suominen $\mathrm{P}$, et al. Gabapentin for the prevention of postoperative pain after vaginal hysterectomy. Pain (2004) 110:175-81.

74. Pandey CK, Navkar DV, Giri PJ, et al. Evaluation of the optimal preemptive dose of gabapentin for postoperative pain relief after lumbar diskectomy. J Neurosurg Anesthesiol (2005); 17:65-8.

75. Turan A, Kaya G, Karamanlioglu B, Pamukçu Z, Apfel CC. Effect of oral gabapentin on postoperative epidural analgesia. Br J Anaesth (2006) ;96:242-6.

76. Al-Mujadi H, A-Refai AR, Katzarov MG, Dehrab NA, Batra YK, Al-Qattan AR. Preemptive gabapentin reduces postoperative pain and opioid demand following thyroid surgery. Can J Anesth (2006) ;53:268-73

77. Ménigaux C, Adam F, Guignard B, Sessler DI, Chauvin M. Preoperative gabapentin decreases anxiety and improves early functional recovery from knee surgery. Anesthesia and analgesia. 2005 May;100(5):1394. 
78. Chouinard G, Beauclair L, Belanger MC.

Gabapentin: long-term antianxiety and hypnotic effects in psychiatric patients with comorbid anxiety-related disorders. Can J Psychiatry. 1998;43:305.

79. Pollack MH, Matthews J, Scott EL. Gabapentin as a potential treatment for anxiety disorders. Am J Psychiatry. 1998;155:992-3. [PubMed]

80. Pande AC, Pollack MH, Crockatt J, et al. Placebo-controlled study of gabapentin treatment of panic disorder. J Clin Psychopharmacol. 2000;20:467-71.

81. de-Paris F, Sant'Anna MK, Vianna MR, et al. Effects of gabapentin on anxiety induced by simulated public speaking. J Psychopharmacol. 2003;17:184-8

82. de-Paris F, Busnello JV, Vianna MR, et al. The anticonvulsant compound gabapentin possesses anxiolytic but not amnesic effects in rats. Behav Pharmacol. 2000;11:169-73.

83. Lynch EP, Lazor MA, Gellis JE, et al. Patient experience of pain after elective noncardiac surgery. Anesth Analg. 1997;85:117-23.

84. Kalkman CJ, Visser K, Moen J, et al. Preoperative prediction of severe postoperative pain. Pain. 2003;105:41523.

85. Rose MS, Kam PC. Gabapentin: pharmacology and its use in pain management. Anaesthesia. 2002;57:451-

62. 